\title{
NGOization of Islamic Charity: Claiming Legitimacy in Changing Institutional Contexts
}

\author{
Kaja Borchgrevink $^{1,2}$ (1)
}

Published online: 25 July 2017

(C) The Author(s) 2017

\begin{abstract}
Islamic welfare organizations are currently going through processes of 'NGOization'. Drawing on qualitative data from Pakistan, Norway and the UK (2012-2015), this article examines how two Islamic welfare organizations which are embedded in Islamic political movements, become 'Muslim NGOs'. The NGOization of Islamic charity signifies not only a change in organizational structure and legal status, but also more profound changes in organizational discourse and practice, and in the ways the organizations make claims to legitimacy. To claim legitimacy as providers of aid in changing institutional environments, the organizations draw on both religious and professional sources of authority. By analysing the NGOization of Islamic charity, the paper brings out the importance of normative frameworks in shaping organizational legitimacy and sheds light on the continued significance of both moral and transcendental aspects of the discourses, practices and identities of Muslim NGOs.
\end{abstract}

Keywords Charity · Islam · Development · NGOs · Pakistan

Résumé Les organisations de protection sociale islamiques sont actuellement soumises à des processus de transformation dans le but d'en faire des ONG. Inspiré de données qualitatives du Pakistan, de la Norvège et du Royaume-Uni (2012-2015), le présent article étudie la façon dont deux organisations de protection sociale islamiques intégrées à des

Kaja Borchgrevink

kaja@prio.org

Peace Research Institute Oslo (PRIO), Oslo, Norway

2 Norwegian University of Life Sciences (NMBU), Ås, Norway mouvements politiques deviennent des « ONG musulmanes ». La transformation du contexte de bienfaisance islamique signifie non seulement la modification de la structure et de l'état juridique des organisations, mais aussi des changements beaucoup plus profonds des discours et pratiques organisationnels, ainsi que des façons dont les organisations affirment leur légitimité. Pour affirmer leur légitimité en tant que prestataires d'aide dans des environnements institutionnels changeants, les organisations font appel à des sources de pouvoir à la fois religieux et professionnel. En analysant la transformation du contexte de bienfaisance islamique, le présent article rappelle l'importance des cadres normatifs dans la structuration de la légitimité organisationnelle, et il jette la lumière sur la place imposante qu'occupent les facteurs moraux et transcendantaux dans les discours, pratiques et identités des ONG musulmanes.

Zusammenfassung Islamische Wohlfahrtsorganisationen durchlaufen derzeit Prozesse, um sich in NROs umzuwandeln. Beruhend auf qualitativen Daten aus Pakistan, Norwegen und Großbritannien (2012-2015) untersucht dieser Beitrag, wie zwei islamische Wohlfahrtsorganisationen, die in islamischen politischen Bewegungen eingebunden sind, „muslimische NROs“ werden. Die Umwandlung von islamischen Wohlfahrtsorganisationen in Nichtregierungsorganisationen bedeutet nicht nur eine Änderung der Organisationsstruktur und der rechtlichen Stellung, sondern behinhaltet auch tiefgreifendere Änderungen des Diskurses und der Praxis der Organisationen und wirkt sich auf die Art und Weise aus, in der die Organisationen Legitimität beanspruchen. Um Legitimität als Anbieter von Hilfeleistungen in sich stets ändernden institutionellen Umgebungen $\mathrm{zu}$ beanspruchen, berufen sich die Organisationen sowohl auf religiöse als auch auf professionelle Autoritätsquellen. Mittels einer Analyse des 
Umwandlungsprozesses der islamischen Wohlfahrtsorganisationen hin zu NROs betont der Beitrag den Stellenwert normativer Rahmenwerke zur Gestaltung der Legitimität einer Organisation und erklärt die anhaltende Bedeutung der moralischen und transzendenten Aspekte der Diskurse, Praktiken und Identitäten muslimischer NROs.

Resumen Las organizaciones islámicas de bienestar social están atravesando actualmente procesos de "ONGización". Recurriendo a datos cualitativos de Pakistán, Noruega y el Reino Unido (2012-2015), el presente artículo examina cómo dos organizaciones islámicas de bienestar social que están integradas en movimientos políticos islámicos, se convierten en "ONG musulmanas". La ONGización de la beneficencia islámica significa no solamente un cambio en la estructura organizativa y el estatus legal, sino también cambios más profundos en el discurso y la práctica organizativas, y en las formas en las que las organizaciones reclaman legitimidad. Para reclamar legitimidad como proveedores de ayuda en entornos institucionales cambiantes, las organizaciones recurren tanto a fuentes de autoridad religiosas como profesionales. Mediante el análisis de la ONGización de la beneficencia islámica, este documento llama la atención sobre la importancia de los marcos normativos a la hora de dar forma a la legitimidad organizativa, y arroja luz sobre el constante significado tanto de aspectos morales como trascendentales de los discursos, prácticas e identidades de las ONG musulmanas.

\section{Introduction: Changing Landscapes of Aid}

'We were the first to reach. We had 20,000 volunteers we could mobilize immediately', a manager from the $\mathrm{Al}$ Khidmat Foundation (ALKF) said, when asked about the organization's response to the massive earthquake that struck northern parts of Pakistan on 8 October 2005. Islamic aid organizations, including the ALKF, were among the first organizations to access the victims of the earthquake (Candland and Qazi 2012; Wilder 2010), well before the Pakistani Army, the United Nations agencies and international non-governmental organizations ${ }^{1}$ (NGOs) (Strand and Borchgrevink 2006).

Over the last ten years, in the wake of earthquakes, floods and internal displacement, Islamic aid organizations have entered the mainstream field of aid and development in Pakistan. ${ }^{2}$ Working alongside national and international

\footnotetext{
${ }^{1}$ In this paper I adopt Gerard Clarke's (1998, p. 36) definition of NGOs as 'private, non-profit, professional organizations with a distinctive legal character, concerned with public welfare goals'.

2 I use 'aid and development' as shorthand for the international aid system, including both humanitarian and development aid, that while
}

aid agencies, the organizations that have been traditionally orientated towards welfare and charity have grown in scale and scope, and they have undergone massive professionalization. As expressed by another representative of the ALKF, 'there was a need to catch up with the foreign NGOs ... Why should the Islamic organizations lag behind?' In his view, because so many disasters and conflicts today affect Muslim communities, 'we need to be there to be part of this, to offer help'. This underlines an obligation to help, but also a perceived need to not be left behind, and for Islamic organizations to claim their space as rightful and legitimate providers of aid.

What we see in Pakistan is part of a broader trend where Islamic charities and aid organizations are becoming significant actors in the field of mainstream aid and development (Juul Petersen 2012a, b), increasingly counted among the 'new humanitarians' (Sezgin and Dijkzeul 2015). However, after $9 / 11$ and the ensuing 'War on Terror', the legitimacy of Islamic charities and aid organizations has been questioned. Such entities have been severely scrutinized, as a consequence of being 'Islamic', and having to prove that they are not financing terror (Juul Petersen 2012a, b; Khan 2012; Thaut et al. 2012).

This article examines the NGOization ${ }^{3}$ of Islamic charity through a study of two Islamic aid organizations originating in Pakistan, namely the ALKF and the Minhaj Welfare Foundation (MWF). Drawing on qualitative data from Pakistani Punjab, Oslo and London, I examine what this NGOization process has entailed, and how it has affected the ways in which organizations make claims to legitimacy.

A number of factors have contributed to the NGOization of Islamic charity in Pakistan. On the one hand, the massive and acute need for humanitarian assistance following the 2005 earthquake, repeated floods and long periods of internal conflict, opened the aid field to 'new' actors and provided an opportunity for these organizations to step up to the challenge. On the other hand, the constraints posed by the stigmatization of Islamic aid organizations made the organizations eager to professionalize. These external factors have prompted internal processes of change, seen in the organizations' strategies to professionalize and to establish formal independence from the political parties. These processes also affect the ways in which Islamic charity, aid and development are conceived and practised in these organizations.

\footnotetext{
Footnote 2 continued originating in the West, currently dominates globally and sets standards for aid provision (Juul Petersen 2016).

${ }^{3}$ NGOization refers to processes of professionalization and organizational change.
} 
The transformation from religio-political volunteerbased welfare organizations to professional humanitarian and development NGOs brings new stakeholders to the organizations. Both the ALKF and the MWF are reaching out beyond their old support base of party members and sympathizers, to new potential partners and donors (governments, NGOs and aid agencies) in the mainstream aid and development field, as well as to the broader public in Pakistan and beyond. To claim legitimacy in changing institutional environments, the organizations combine religious and professional authority, relating to the Islamic tradition on the one hand and to the mainstream aid and development discourse and practice on the other. Shifting towards the aid and development sector the organizations adopt or adapt some elements, while they reject or avoid others.

I begin this article by contextualizing the study of Islamic charity, aid and development before I outline a framework for analysing the NGOization of Islamic charity, combining insights from the anthropology of development with neo-institutional theory. Moving on to the analysis, first I present two organizations, the ALKF and the MWF, and examine the NGOization of Islamic charity. Second, I analyse how this process affects the ways in which organizations make claims to legitimacy among different stakeholders. Next, I give attention to how, in this process, the organizations combine different sources of authority. I conclude by discussing how, by balancing different sources of authority, the organizations become 'Muslim NGOs'.

\section{Islamic Charity, Aid and Development}

Charity is central to Islamic doctrine and Muslims' religious practice. There are a number of very concrete institutions for giving charity detailed in the Quran, including the obligatory zakat and several forms of voluntary almsgiving, including sadqa (Benthall 1999). Giving charity is a personal religious act, and according to Islamic teachings, the right hand should not know what the left hand is doing. This makes it difficult to gauge the scale of Islamic charity in Pakistan and elsewhere (IRIN 2012). In the form of private donations, Islamic charity is not counted as part of development assistance. While much Islamic charity is given to family and neighbours, changing hands between individuals, considerable amounts of money are channelled through charities and aid organizations (Aga Khan Development Network [AKDN] 2000; Pakistan Centre of Philanthropy [PCP] 2010).

In Pakistan, organized Islamic charity takes many forms. It includes daily communal meals arranged at mosques and shrines, education offered through religious seminaries and schools and a diversity of initiatives in health, microfinance, social welfare and clean water provision by Islamic charity and aid organizations operating at local and national levels, some with transnational reach (GhausPasha and Iqbal 2003; Kirmani 2012; Strothmann 2013). Unlike among most other political parties in Pakistan, charity and welfare work has been a central feature of religio-political parties, many of whom run welfare organizations (Iqbal and Siddiqui 2008).

The welfare work of religio-political or 'Islamist'" movements in the Middle East, East Asia and South Asia has seen increased scholarly attention over the past decade (Clark 2004; Göçmen 2014). However, these studies have a tendency to focus on political actors, which arguably provides a narrow view of Islamic aid organizations. As these actors are increasingly contributing and collaborating in the mainstream aid and development field, it becomes relevant to examine them as development actors.

This paper seeks to extend our knowledge about actors who are inspired by alternative normative religious and ideological frameworks, rather than to discuss those who dominate the mainstream field of aid and development. While many of today's major humanitarian and development NGOs started as faith-based initiatives, the mainstream discourses and practices of aid and development have gradually adopted a largely secularized and material conception of development and approaches to aid (Agensky 2013), in which the 'the religious' is seen as separate from 'the secular' (Tomalin 2015a).

Although there has been an increased interest in religious, or so-called faith-based organizations (FBOs) over the past decades (Berger 2003; Clarke 2008; Clarke and Ware 2015), the role of religion for organizational legitimacy has received relatively scant attention. Notable exceptions exist: these include the work of Juul Petersen, who examines how transnational Muslim NGOs give meaning to what they do and construct legitimate 'ideologies of aid' (Juul Petersen 2016, p. 8), and the work of Thaut, Gross Stein and Barnett, who examine the legitimacy dilemmas faced by Islamic Relief, a major Muslim NGO based in the UK (Thaut et al. 2012).

Situated at the peripheries of the international aid and development field, such organizations are rarely acknowledged as development actors, either because they are religio-political and seen as vote-seeking, or because their approach to development is seen as charity-orientated, or otherwise in conflict with the secular liberal norms dominant in the mainstream Western-origin aid and development tradition. I believe religio-political actors are

\footnotetext{
4 I describe these organizations as 'religio-political' because it is a more descriptive term, and in order to avoid the connotations attached to the term 'Islamist' in contemporary politics and media debate.
} 
important to study-precisely because they present alternative conceptions of aid, sometimes to the extent of outright rejection of a religious/secular divide. This approach departs from scholarship which analyses the potentials and pitfalls of religion in development, where some argue that the religious proximity of FBOs offers a comparative advantage vis-à-vis beneficiaries (Benthall 2012; De Cordier 2009), while others warn against jumping the 'faithbased bandwagon', cautioning against the dangers of endorsing the views of religious actors (De Kadt 2009). Instead, this paper recognizes religion as a potentially significant dimension of social reality which ought to be considered when attempting to understand organizational legitimacy as a social construction.

\section{Studying the NGOization of Islamic Charity}

The term 'NGOization' has been used to describe processes of professionalization, institutionalization, depoliticization and demobilization of social movements (Alvarez 2009; Chahim and Prakash 2014). As applied to Islamic charity, analysing how welfare organizations embedded in religiopolitical movements become development NGOs, the use of this word signifies not only changes in organizational structures or legal status, but also more profound changes in organizational discourses, and in the ways the organizations make claims to legitimacy.

The proliferation of the development NGO from the 1980 s, together with its central role in the provision of humanitarian and development aid over the last three decades, has made the NGO a favoured, and contested, object of study (Banks et al. 2015). Two contrasting views of NGOs are often identified in the literature: NGOs as efficient service providers and NGOs as civil society actors that can provide development alternatives (Mitlin et al. 2007). Although these views are very different understandings of NGOs, both are rather static and normative and leave little room for actors 'inspired by alternative ideological or religious frameworks' (Hilhorst 2003, p. 9). A third view, adopted in this paper, shifts the focus to what it is that makes organizations into NGOs, seeing NGOs as complex actors, situated in particular social and political contexts (Hilhorst 2003; Juul Petersen 2016; Novak 2013). As pointed out by Hilhorst (2003, p. 6), the NGO label is more than a legal term; it is used as a 'claim-bearing label', through which organizations indicate that they conform to the expectations of a certain type of professional aid and development organization.

In her study of transnational Muslim NGOs, Marie Juul Petersen directs attention to the ways in which organizations 'produce, contest and present meaning, in the process making claims to legitimacy' (Juul Petersen 2011, p. 31).
Juul Petersen finds what she describes as a process of 'Islamization of aid' (Juul Petersen 2012a, b, p. 4). By contrast, the current article focuses on the NGOization of Islamic charity. The article complements recent analysis of transnational Muslims NGOs, by shedding light on the actors originating in the Global South. These actors emerge as significant in the mainstream aid field but have been given less scholarly attention (for an exception see Salehin 2016).

Inspired by the work of Marie Juul Petersen and Dorothea Hilhorst, I explore the interface between different discourses of aid, related to ideals and practices of Islamic charity on the one hand and the mainstream Western-origin tradition of humanitarian and development aid on the other (Juul Petersen 2016). In this study, I do not take 'Islam', 'aid' or 'development' to be predefined and static concepts, but view them as constructions that emerge and are given meaning in particular contexts. Following Lincoln (2010), I take a view of religion as something that can be ascribed to social practice, meaning that anything can potentially be attributed religious significance, including aid and development.

As private actors, NGOs need to claim legitimacy to exist, to obtain the required legal status and to secure both financial and moral support. Over the last decade, NGOs have seen increased criticism for failing to deliver, for not being representative and for lacking accountability (for a discussion, see Lister 2003). This often-referred-to "crisis of legitimacy' has placed legitimacy questions at the centre of the study of NGOs in development and humanitarianism (Thaut et al. 2012; Walton et al. 2016).

In the study of NGOs, however, legitimacy has often been treated as a technical issue, with the emphasis placed on accountability, efficiency and representativeness (Lister 2003 , p. 178). Departing from this technical approach to organizational legitimacy, scholars have drawn on insights from neo-institutional theory (Brinkerhoff 2005; Juul Petersen 2016; Lister 2003), which emphasize the importance of normative environments in shaping organizational structure, content and behaviour (Meyer and Rowan 1977; Meyer and Scott 1983). Neo-institutional scholars assert that the legitimacy of an organization depends on its conformity, or resonance, with the discourses that are dominant among its stakeholders, both internal and external to an organization (Meyer and Scott 1983). Importantly, it is not the nature of the organization that gives legitimacy, but the stakeholders and constituents of an organization that accord legitimacy to it. Legitimacy is accorded to an organization if its social and moral purpose is consistent with the values and expectations of its stakeholders. As such, a change in discourse and practices in an organization or among its stakeholders, will affect the legitimacy of the organization. As Brinkerhoff points out, to be legitimate, 
organizations need to be 'doing the right things', 'doing the things right' and need to be seen as 'right for the job' (Brinkerhoff 2005, p. 4).

Three broad dimensions of legitimacy are commonly distinguished in the neo-institutional literature: normative, pragmatic and cognitive (Brinkerhoff 2005; Ossewaarde et al. 2008; Suchman 1995). Normative legitimacy is accorded to an organization when it reflects socially and morally acceptable or desirable norms, standards and values. These can be formal law, and informal norms and codes of conduct. Pragmatic legitimacy concerns the instrumental value of the organization for its stakeholders and constituents, and is accorded to an organization if it fulfils the needs and interests of these parties. Cognitive legitimacy is given when an organization pursues objectives and activities that are considered appropriate in a given context, seen as natural and left unquestioned by stakeholders (Brinkerhoff 2005). An analysis of these three dimensions of legitimacy is useful to shed light on the significance of the normative environment in shaping organizational discourses and in bringing out how organizations draw on different sources of authority when making claims to legitimacy among different stakeholders, in different contexts.

Discourse is here understood in a broad sense, not as a coherent and fixed set of ideas, but as assemblages of ideas, values and practices produced and reproduced in the interface between diverse social actors (Long 2001, p. 18). Following Grillo, 'a discourse [of development, for example] identifies appropriate and legitimate ways of practising development as well as speaking and thinking about it' (Grillo 1997, p. 13). As such, discourse influences the institutional environments in which organizations exist. To be legitimate, organizations need to conform to dominant discourses of aid and development existing in particular contexts (Lister 2003, p. 188). An organization's legitimacy may change-be strengthened or diminishedas the normative, pragmatic and cognitive understandings of aid and development change (Lister 2003, p. 187). Organizations, however, are not only passively shaped by external factors, but can also act to enhance their legitimacy by responding to stakeholders' expectations. One way organizations can achieve this is by aligning with established authority through association with particular forms of knowledge, text and symbols (Lister 2003; Meyer and Scott 1983).

\section{Context, Cases and Methods}

The ALKF and the MWF are two of the largest and bestestablished Islamic aid organizations in Pakistan. The ALKF originates in the Jamaat-e-Islami (JI), Pakistan's oldest Islamist party established in 1941, and in the religiopolitical ideologies of its founder, Sayyid Abul Ala Maududi (Nasr 1994). The MWF is part of the Minhaj-ulQuran International (MQI), a 'neo-Sufi' religious organization established in Pakistan in 1980 by religious scholar and politician Dr Tahir-ul-Qadri (Philippon 2014). While the organizations represent two different Islamic traditions, both are modern Islamic revivalist movements, which can be seen as working to advance modern Islamic states and societies. Hence, the organizations represent a specific subset of Islamic aid organizations with religio-political ties and are not representative of all Islamic charity-based actors in Pakistan. Like Islamist organizations elsewhere, they predominantly mobilize among the educated urban middle class and other elites (Iqtidar 2011; Philippon 2012). In this respect they are not unlike secular NGOs, which are also commonly run by the middle class and elites (Bano 2008). Originating in Pakistan, both movements have spread through the Pakistani diaspora around the world and form part of complex transnational networks. ${ }^{5}$

Both the MWF and the ALKF are part of religious movements promoting 'gender-traditional' ideologies (Burke 2012) where men and women have different but complementary roles, rights and duties. As such, both organizations practise gender segregation, ${ }^{6}$ and although the organizations provide assistance to women and men alike, both the MWF and the ALKF are staffed by men only. The organizations are collaborating with the respective movements' women's organizations (the Minhaj Women League and the Al Khidmat Women Trust) in the implementation of activities. $^{7}$

The current article is based on multi-sited, qualitative fieldwork in Pakistani Punjab, Oslo and London, carried out in the period 2012-2015. It draws on a total of 72 interviews. Thirty are semi-structured (15 with men and 15 with women) associated with the two religio-political movements in Pakistan, and 16 are with individuals (12 with men and 4 with women) who work in other NGOs and for the Government of Pakistan. The data from Pakistan are supplemented by 26 interviews in other countries, with people mainly of Pakistani origin who are associated with the two movements. In Oslo, 24 interviews (12 with men and 12 with women) took place, and the last two interviews were both with men in London, during the same period.

\footnotetext{
5 For a discussion on the transnational organization of Islamic charity see reference removed for peer review.

${ }^{6}$ While gender segregation is uncommon among NGOs in Pakistan, most political party structures are segregated and women's political activism is commonly organized through separate women's wings (Sahi 2015).

${ }^{7}$ For a more in-depth discussion of gender dimensions of Islamic charity and development in these organizations see reference removed for peer review.
} 
The study also draws on written material made available by the organizations, on information from the websites and social media, as well as observation from visits to the organizations' offices, project sites and events. I have interviewed workers and volunteers about their ideas about development, their aims and activities, the history of the organizations, their relationship to other actors, their personal backgrounds and their motivation for working in the organizations. This study is based on how the organizations and the interviewees working in these organizations present themselves and what they do. As such, it is a study of how the organizations make claims to organizational legitimacy; it is not an analysis of their ability to gain or maintain legitimacy. While an analysis of the perspectives of the beneficiaries would merit interest, it lies outside the scope of this study.

\section{Catching Up: From Islamic Charity to Aid and Development}

The ALKF originates in the relief efforts of JI activists on behalf of refugees fleeing from India to Pakistan during partition in 1947 (Nasr 1994). Initially, income from selling animal hides collected during Eid ul Adha (the annual ritual animal sacrifice) was used to support welfare projects. The MWF is the welfare organization of Minhaj-ulQuran International (MQI). The welfare and charity activities of Minhaj-ul-Quran were initially started in Pakistan under the Minhaj Welfare Society in 1989. Members of the MQI in Pakistan and the diaspora-in the UK, Norway and elsewhere-donated money to feed 'the poor' during the month of fasting (Ramadan) and had the ritual animal sacrifice (qurbani) at Eid ul Adha arranged through the welfare society. The income from the animal skins sold afterwards was used for welfare. Starting out as distributors of peoples' alms and facilitators of religious ritual, the activities of the two organizations were closely linked to the traditional Islamic institutions for giving charity. This has changed in the process of NGOization.

In the NGOization of Islamic charity, we can depict four distinct trends, which are also identifiable in the two organizations. These are: (1) a shift in self-(re)presentation from partisan movement-orientated welfare organizations to neutral providers of aid; (2) a change in focus of activities from charity-based community welfare to humanitarian aid and development; (3) a shift from volunteerism to employment of salaried development professionals; and (4) a broadening of funding sources, from relying almost exclusively on community members to reaching out to broader donor bases, including institutional donors.

\section{From Party to Impartiality}

Welfare and social justice have been central to the ideologies of both the JI and MQI, as ways of mobilizing voters, but also as demonstrating commitment and practising movement ideology (Bano 2012, p. 88). In the case of the JI, as described by the movement's main ideologue, Maududi, at a party conference in the context of the 1958 elections in Pakistan, the importance of welfare work is revealing (cited in Bano 2012, p. 88): 'First of all it brings intellectual change in people; second [it] organises them in order to make them suitable for the movement; thirdly, it reforms society through social and humanitarian work; and finally it endeavours to change the leadership'.

Both the ALKF and the MWF have their origins in religio-political movements and their political parties. The ALKF was officially registered as an NGO with the Government of Pakistan in 1990. Since 2004, the ALKF has not had any formal association with the JI, yet the informal ties between them remain strong. In contrast to the ALKF's official disassociation from the political party, the MWF is an integrated part of the MQI's overall organizational structure. In Pakistan, the MWF main office is located in the MQI Markaz in Lahore, the movement's spiritual and organizational headquarters. In the MWF, the London office has been established as a UK charity, with the other European diaspora branches functioning as fundraising offices.

From having identities closely tied to religio-political movements, the organizations are now presenting themselves as global humanitarian actors. The transformation from community welfare organizations to NGOs involves a change in organizational identity, particularly in the ways the organizations present themselves to external audiences. Today, the ALKF introduces itself as an organization that is 'dedicated to humanitarian services'. ${ }^{8}$ The MWF presents itself as a 'worldwide humanitarian development organization'. Moving into the mainstream aid and development field and positioning themselves as legitimate NGOs, both organizations have changed the ways they perceive and present themselves. One MWF staff member explained:

MWF, we are not a religious organization, we are faith-based organization. We perceive our self as a worldwide humanitarian organization. We don't distinguish by Muslims or non-Muslims.

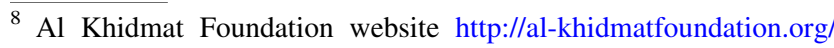
(accessed 3 February 2013).

${ }^{9}$ https://www.minhajwelfare.org/our-aims-and-objectives/ (accessed 1 June 2016).
} 
According to ALKF, they similarly 'provide services to all, without discrimination'. ${ }^{10}$ From being welfare organizations focusing on the local predominantly Muslim community, both organizations have consciously included Christians and Hindus among beneficiaries in Pakistan and have expanded programme areas to include activities outside Pakistan (such as relief response to Haiti and Japan, and support to victims of conflict in Syria and Palestine). This change in self-(re)presentation is a clear break with their earlier identity as community welfare organizations, catering mainly to followers of the same faith. In this way, the organizations can be seen as aligning themselves with the core principles in mainstream aid culture: humanity, impartiality, neutrality and independence. ${ }^{11}$ Yet, there are other areas where alignment with universalistic frameworks remains problematic. The institutionalization of gender norms of segregation and complementarity in the organizations, for example, are areas where both organizations clearly break with norms of gender equality dominant among actors in the mainstream aid and development field (Tomalin 2015b).

\section{From 'Community Welfare' to 'Relief and Development'}

Originally the activities of ALKF and the MWF related to distribution of food, clothes and gifts for Eid, qurbani meats, blankets and clothes in the winter, cash grants to people in dire economic situations, dowry boxes for young couples to get married and funding for the construction of mosques. Gradually, the organizations have expanded their welfare activities and built up extensive and specialized sectoral programmes, shifting the focus of activities to humanitarian relief, as well as to long-term development through education and health. The ALKF is also offering microfinance and support for entrepreneurship and business development. The original focus on purely charity-orientated welfare work has been reduced to being one of many programme areas, now labelled as 'community services' and 'seasonal activities'. This signals a change, in ways of thinking about and practising aid - to include notions both of immediate needs-and longer-term societal development through investments in education, income generation and health. A common view of individuals interviewed in both organizations was that there is a need for the

\footnotetext{
10 Al Khidmat Foundation website http://al-khidmatfoundation.org/ (accessed 3 February 2013).

11 The key humanitarian principles, first adopted by the International Movement of the Red Cross and Red Crescent at its 20th international conference in Vienna in 1965 . The principle of impartiality demands that assistance should be based on need and that it should not discriminate on the basis of nationality, race, religious belief, gender, political opinions or other considerations (Barnett 2005).
}

distribution of food, but that this alone is not enough; as one manager put it: 'it will not affect the needed change'. A member of the ALKF leadership talked about the changing organizational priorities in the following terms:

Al-Khidmat, right now, is focusing more in development sector and we are making programs for advocacy as well. We realize that no matter how big an NGO is it is not possible to resolve all the problems. So we have to go into advocacy so that we can impact the government sector to make the right decisions for an issue [...] like floods. We have a few people, a few experts, working on how to reduce the risk of flood in Pakistan. The report is in progress and we will move forward to the elected members, members of provincial assemblies, members of national assembly, asking them to put that into the policies and so on; so we are moving forward in that manner.

The ALKF is positioning itself in the mainstream aid field, working alongside other humanitarian NGOs in relief efforts and in lobbying the government to make a longerterm impact. It is a member of the NGO coordination body in Pakistan and has recently been accredited by the Pakistan Centre of Philanthropy (the main initiative to vet the credibility of NGOs in Pakistan). It is also actively engaged in transnational initiatives with likeminded Muslim actors (such as the International Federation for Relief and Development).

In comparison with the ALKF, the MWF is smaller and more closely integrated with the transnational religious organization, MQI. However, the MWF has also expanded its activities from charity-based handouts to longer-term development-orientated activities in health and education. The changes in the MWF are largely driven by its UK office, which has developed into a European headquarter. The UK office has rebranded the MWF, given it a new image, presenting it as a modern humanitarian organization. In the UK, the MWF compares itself with the larger, well-established Islamic Relief and Muslims Aid. To move into the mainstream aid and development field, and into new domains like advocacy, new knowledge and expertise is needed. To meet these requirements, both ALKF and MWF have professionalized.

\section{From Volunteers to Professional Staff}

Being the welfare organizations of religio-political movements, both the ALKF and the MWF were first created and run by volunteers. The ALKF claims to draw from a pool of some 100,000 volunteers across Pakistan, predominantly JI party members and sympathizers (Kirmani and Zaidi 2010). Closely linked to the religio-political movements of 
the JI and MQI, the welfare, relief and development work of the ALKF and the MWF has been tightly integrated with the other activities of these movements, ${ }^{12}$ focusing in particular on spreading the teachings of Islam (dawa), imparting religious training (tarbiyat) and with more direct political activism. Volunteering is seen as sadqa, a way of doing good deeds, a way of practising religion and of sacrificing 'in the way of God'.

A central part of the professionalization has been the employment of development experts with experience from relief and development work and the training of volunteers. Membership in the religio-political movements is not a requirement for working with either the ALKF or the MWF, and both organizations have non-party member development professionals and volunteers. At the time of research, the ALKF Pakistan had some 60 salaried staff, while the MWF had five full-time employees at the Pakistan office and five at the UK office. Although the number of salaried professional staff is small compared to the large number of volunteers, both the ALKF and the MWF are introducing a new type of institutional stakeholder to their organizations. By employing development professionals with degrees in development and experience from the aid and development sector, they are bringing new norms and standards to the organizations. The employment of salaried professionals challenges the ideals of volunteering as sadqa and self-sacrifice, even though the employees emphasized that their salaries were lower than in other NGOs, and were therefor in keeping with Islamic ideals of modesty and simplicity.

\section{From Alms to Institutional Funding?}

Unlike many NGOs in Pakistan which commonly rely on institutional donor funding (Bano 2008, p. 2300), the activities of the ALKF and the MWF have primarily been funded by Islamic charity, in the form of zakat and sadqa, the sale of qurbani hides and other regular contributions from party members (Bano 2012, p. 89). In recent years, however, both organizations have expanded their funding bases. The ALKF mobilizes funds through the JI organizational structure in Pakistan, through members' contributions and through local charity and fundraising eventsbut also through online campaigns and networks of likeminded Muslims in Pakistani diaspora communities in the Gulf, Europe and North America. With web pages in Urdu, English, Arabic and Turkish, the ALKF is proactively reaching out to potential sympathizers and supporters though registered charity organizations, individual donations and mosque-based networks (reference removed for

\footnotetext{
12 This is still the case in the all-women organizations (reference removed for peer review).
}

peer review). The ALKF has expanded its donor base to include funding from institutional donors, although in practice the organization has received limited funding from mainstream donor agencies. At the time of research, the ALKF had received small-scale funding for flood relief from the Government of Japan, a donor government seen by the organization as politically neutral. Both the ALKF and the MWF are careful who they partner with; they want to be seen as independent, particularly from the politics of the US and UK governments. The ALKF has expanded its collaboration with the government and with United Nations (UN) organizations as well as national and international NGOs in providing humanitarian assistance and is taking active part in humanitarian coordination fora. In the words of one ALKF employee:

We have our own style of work, but we see that we cannot work alone ... We have started the liaison with government departments; we have become member of the National Disaster Risk Reduction forum, with all the international and international organization that works on disaster risk reduction in the country ... We are trying to become member of the National Humanitarian Network ... by the will of God [Insha'Allah], hopefully, in the future, we will become a member of that network.

By contrast, the MWF as an integrated part of the MQI organizational structure is still largely funded by individual donations channelled through the MQI local organizational chapters in Pakistan and the diaspora. But the MWF is also expanding its donor base, seeking to attract donors from outside the movement, particularly in the diaspora. The UK office of the MWF has introduced new fundraising events that are not linked to religious festivals (including annual fundraising challenges such as walking the Great Wall of China or climbing the tallest mountain in the UK).

As this analysis reveals, the NGOization of Islamic charity involves the processes of both professionalization and depoliticization, with the organizations presenting themselves as modern and professional aid organizations who provide neutral and impartial assistance to people in need. In many ways, the NGOization of Islamic charity resembles the institutionalization of development (Boli and Thomas 1999) and humanitarianism (Barnett 2005), where discourses of aid and development have been institutionalized through processes of professionalization, standardization and specialization. Both organizations have professionalized by hiring development experts in management positions and conducting training of volunteers. They have also standardized their operations by adopting ISO standards, introduced new management practices and sought accreditation from recognized authorities and specialized by dividing the work into sectoral programmes and 
developing expertise in specific areas. But the NGOization process has not only affected the organization of Islamic charity; it has also involved profound changes in the ways of practising, conceiving and talking about what they do. From being distributors of alms to the local community, the organizations have now become aid and development NGOs.

\section{Claiming Legitimacy: Religious and Professional Authority}

The NGOization of Islamic charity has introduced new stakeholders to the organizations, both external to the organizations in terms of partners and donors from the mainstream development industry and internal to the organizations through the employment of development experts. In the following section, by analysing how the two organizations lay claim to legitimacy, I argue that to meet the expectations of diverse stakeholders, the organizations seek to combine multiple sources of authority: religious and professional.

The formal development NGO can, as an ideal type, be described as operating within a secular frame, emphasizing adherence to key humanitarian principles, and as following institutional norms established to ensure efficiency, accountability and representation (Barnett 2005). Aid is to be given based on need, not on particular solidarity bonds (such as those based on religion or nationality, for example). In order to be legitimate humanitarian and development actors, organizations need to adhere to these shared norms and standards, framed in a shared language and set of symbols. These norms constitute what can be described as 'professional authority' (Juul Petersen 2016, p. 74).

As opposed to the professional authority central to aid and development discourse and practice, Islamic charity can be seen as legitimized by religious authority, claims to transcendental power and truth (Lincoln 2010). As welfare organizations integrated into religio-political movements, the ALKF and the MWF have claimed legitimacy by being appropriate distributors of alms. Both organizations were founded by charismatic religious leaders, Sayyid Abul Ala Maududi and Dr Tahir-ul-Qadri, respectively. The teachings of the movement's leaders have been actively used by the organizations to attract volunteers and to motivate people to donate. The organizations make extensive use of media in the forms of print, audio, video and online. The ALKF and MWF websites present their programmes and activities, but also provide detailed information about various religious duties and rituals, and specify how, what and to whom they apply. Both organizations offer online donation services, where, with a click, a donor can determine whether what they give is zakat or for another specific purpose. Religious teachings, text and symbols constitute an important source of authority employed by the organizations to claim legitimacy among their traditional constituencies, mainly members and sympathizers of the religio-political movements and individual donors.

\section{Normative Legitimacy: Managing Aid and Alms}

As asserted in the new institutional literature, normative legitimacy is accorded to an organization when it reflects socially and morally acceptable or desirable norms, standards and values (Brinkerhoff 2005). For aid and development NGOs, normative legitimacy is commonly produced through formal legal requirements (such as legal registration or permits to operate), norms related to managerial practices, accountability and representation (Lister 2003) and norms related to approaches to aid and development (what kind of aid, development and for whom). In order to claim normative legitimacy, as do NGOs, from other actors in the aid and development sector (for example, governments and donor agencies), the ALKF and the MWF have professionalized; they have hired new staff and trained volunteers and introduced new operating standards and procedures. They are adopting organizational practices, principles and ways of doing things from the mainstream aid and development discourse and practice. At the same time, both organizations are still managers of Islamic charity.

In the Islamic tradition, there exists a set of very concrete institutions for giving charity, which provides directions for how, when and to whom different types of alms should be given and managed. In the case of zakat, for example, eight categories of recipients are detailed in the Quran, the first two being 'the poor' and 'the needy'. ${ }^{13}$ Who the 'poor' and 'needy' are is defined by the nisab, the threshold distinguishing who has to pay-or receivezakat. $^{14}$

When people give Islamic charity, it is often for specific purposes, with particular intentions in mind. Intention (niyat) is central in Islam; it is the intention of a person's action that is measured by God. The intention can be to help the poor, relieve suffering and contribute to social

\footnotetext{
13 The categories of worthy recipients of zakat outlined in the Quran (Surah 60. verse 9): 'the alms are only for the Fuqara' (the poor), and Al-Masakin (the needy) and those employed to collect (the funds); and to attract the hearts of those who have been inclined (towards Islam); and to free the captives; and for those in debt; and for Allah's Cause, and for the wayfarer (a traveler who is cut off from everything); a duty imposed by Allah'.

14 Those with an annual economic surplus above the nisab are required to pay $2.5 \%$ of this as zakat, those with annual economic surplus below the nisab qualify as recipients of zakat. The nisab is calculated based on the value of $3 \mathrm{oz}$ (87.48 grams) of gold or 21 ounces (612.36) of silver, thus changing with market value.
} 
justice, but also to please God. Doing good deeds-like donating or volunteering-is understood to give religious rewards and is a means to attain paradise in the afterlife (akhira). As such, giving charity, volunteering or working for a Muslim NGO is not only for helping people here and now, but is simultaneously an investment by the donors in the life 'hereafter'. Ensuring that the money is utilized as intended is the responsibility of the intermediary-in this case, an NGO-which is an intermediary not only between the donors and the beneficiaries, but also between the donors and God. It becomes the responsibility of the organization to make sure the alms are used for their intended purposes. This is particularly significant in the case of zakat, which can only be used for concrete purposes detailed in the Quran, but equally important when people make donations for other specific purposes. This gives certain direction for how donations can be used and requires particular financial managerial setups, as explained by one ALKF manager:

In our fund management, one thing is very clear: money that is earmarked to a specific project, the money will go to that project. And zakat is a very sensitive issue. When people give zakat, we put it in a special zakat account. Zakat has its own spending account. Like yesterday someone gave us 27,000 rupees, 7000 was for the qurbani [ritual slaughter], 20,000 was for zakat. So as soon as they marked it, we put it in a separate zakat account.

For the ALKF and the MWF, these religious and transcendental dimensions are at least as important, if not more, than the technical aspects of financial transparency and accountability expected by professional NGOs. It illustrates how the rules and 'ways of doing things' are important in the management of alms, and how 'the right way of doing things' differs between institutional environments in which these organizations are situated. In order to claim normative legitimacy among new and old stakeholders, the organizations need to adhere to the norms and standards of professional aid and development NGOs, while adhering to Islamic principles.

Whether non-Muslims can be recipients of zakat is an area of contention, interpreted variously by Islamic scholars and by different Islamic aid organizations. ${ }^{15}$ Scholars of the Hanafi school, dominant in South Asia, commonly interpret zakat as only permissible for Muslims. Both the ALKF and the MWF subscribe to this interpretation, which can be seen as breaking with key humanitarian principles

\footnotetext{
14 Those with an annual economic surplus above the nisab are required to pay $2.5 \%$ of this as zakat, those with annual economic surplus below the nisab qualify as recipients of zakat. The nisab is calculated based on the value of $3 \mathrm{oz}$ ( 87.48 grams) of gold or 21 ounces (612.36) of silver, thus changing with market value.
}

of aid provision without discrimination. As pointed out by Kirmani and Zaidi (2010, p. 18), determining who are considered worthy recipients of zakat can have clear implications for the work of organizations. The ALKF claims not to discriminate on the basis of religion and to provide assistance to all, using funding sources other than zakat—such as sadqa, for instance- to fund their activities directed towards non-Muslims. Here, the organization has devised a strategy that works as long as it is operating in a context where the recipients are mainly Muslim.

\section{Pragmatic Legitimacy: Development Aid Versus Religious Practice}

Pragmatic legitimacy concerns the instrumental value an organization has for its stakeholders and constituents. It is granted to an organization on condition that the organization fulfils the needs and interests of the specified actors (Suchman 1995). Humanitarian and development NGOs claim pragmatic legitimacy by delivering aid. Through helping people in need, offering short-term relief or longerterm development, NGOs claim pragmatic legitimacy by being the intermediaries between donors and beneficiaries and by being efficient, effective and appropriate deliverers of aid. Muslim NGOs also need to be efficient providers of aid, but they have additional otherworldly functions. Helping the poor and people in need is an obligation in Islam, and doing welfare work commonly seen as sadqa, as performing good deeds. Giving to charity is a religious practice that both benefits the individuals in need, and gives religious rewards to those who help. The ALKF and the MWF not only provide a means for giving alms, but they also provide their members, workers and volunteers with ways to practise religion. Religious motivations were significant for the people I interviewed who worked in these organizations; several of the volunteers emphasized the moral obligation to volunteer and underlined how doing service is part of being a good Muslim and of belonging to the religious movements. For these stakeholders, religion constitutes a powerful source of authority, which the organizations make use of when making claims to pragmatic legitimacy among their traditional support base. To claim pragmatic legitimacy in a changed institutional context with new and old stakeholders, the organizations need to be seen as efficient deliverers of aid, providing ways for donors to relieve people of suffering and contribute to societal development here and now, while at the same time offering ways to practise religion, which is an investment in the future, so to speak.

\footnotetext{
15 The UK-based Islamic Relief, for example, does not restrict zakat to only Muslim recipients (see Khan 2012, p. 98).
} 


\section{Cognitive Legitimacy: Natural Managers of Alms and Aid}

Cognitive legitimacy is accorded when an organization pursues objectives and activities that are considered appropriate in a given context. To be awarded cognitive legitimacy in the aid and development field, NGOs need to be seen as natural providers of aid; they need to acknowledged as efficient (cost effective) and effective (delivering what they propose) in appropriate ways (reaching those in need), while adhering to key principles of neutrality and non-discrimination. When NGOs are not seen to live up to these ideals, they risk losing legitimacy. In order to be regarded as legitimate by other development actors (the Government of Pakistan, international NGOs and donor agencies), Islamic aid organizations need to prove that they are not front groups for terrorist organizations, but legal and genuine development NGOs (following established rules and standards); that they are not just distributing charity, but are efficient deliverers of relief and development; and that they are not partisan vote seekers, but are neutral providers of aid without discrimination, embracing the key principles of humanitarian assistance.

While the legitimacy of Islamic charities has been questioned, mainstream 'secular' NGOs seem to be lacking cognitive legitimacy in the Pakistan context. These NGOs have a poor reputation in Pakistan (Grünenfelder 2013); they are frequently criticized on ideological grounds for being 'agents of the West', as advancing anti-Muslim interests, for not delivering what they promise and for being institutions of personal enrichment with individual leaders profiting (Bano 2008). This can be seen as being in direct conflict with the ideals of simplicity and self-sacrifice held high by the Muslim NGOs. If Muslim NGOs wish to claim cultural and cognitive legitimacy among their traditional stakeholders (members and sympathizers of the religious movements) and among the broader Muslim public, they need to be more than NGOs. While professionalism is recognized by the organizations as a requirement of the day, it is not enough: the organizations also need to be seen as 'Islamic'. To do so, the organizations emphasize what they consider to be core Islamic values such as modesty and simplicity, self-sacrifice and volunteering; they offer more modest salaries; they do not drive flashy cars. To claim cognitive legitimacy, the organizations present themselves as modest and modern Islamic alternatives to the mainstream development NGOs.

Drawing attention to the normative, pragmatic and cognitive dimensions of legitimacy helps to bring out the multifaceted and complex nature of claiming legitimacy. Analytical distinctions are useful when trying to make sense of this complexity, although they are difficult to apply in practice since normative, pragmatic and cognitive dimensions of legitimacy overlap (Brinkerhoff 2005). Even so, the analysis in this study reveals how legitimacy changes with context, vis-à-vis the organizations' new and old stakeholders, over time. Importantly, it draws attention to the contextual and relational nature of legitimacy, and the significance of normative environments-religious and ideological-in the construction of legitimacy.

\section{Managing Change: Becoming Muslim NGOs}

The ALKF and the MWF have become complex organizations, advancing a diverse set of norms and procedures, fulfilling multiple functions and projecting multifaceted organizational identities. In order to manage organizational change, the ALKF and the MWF are both adopting strategies through which they can respond to diverse stakeholders' expectations.

It has been well established by institutional theorists (such as Meyer and Scott 1983) that organizational legitimacy can be enhanced through identification with language and symbols. In both ALKF and MWF religious knowledge, texts and symbols have been complemented by technical knowledge and management expertise associated with development professionalism, drawing on the language and imagery of mainstream development and humanitarian aid. Where Islamic texts and symbols were used to inspire and justify action and appeals, reference is now also made to development statistics and UN campaigns. One example of this is the focus on clean water. Giving water to the thirsty is a central teaching in Islam, and providing clean water is a common undertaking of Islamic charity organizations. Over the years, the ALKF has established some 2766 water wells and 1141 hand pumps. According to the AKLF website, 'providing water in this way is a very good way of offering a Sadaqah Jariyah [continuous charity] as the donor can expect to reap Allah's blessings for as long as the well supplies water. ${ }^{16}$ On the organization's new website, clean water is also linked to the UN World Water Day. Importantly, the organization is not discarding the Islamic frame, but is combining it with professional development knowledge, language and symbols. Taking a traditional practice of Islamic charity and reframing it in the language of development can be seen as a way of 'developmentalizing' Islamic charity (Juul Petersen 2016), combining elements from the two different traditions.

Both the ALKF and the MWF are operating on multiple levels and in different contexts, in Pakistan and abroad. In Pakistan, the MWF is known as a provider of welfare in the

\footnotetext{
${ }^{16}$ http://al-khidmatfoundation.org/clean-water/\#sthash.0MPdCCXb. dpuf (accessed 18 January 2016).
} 
neighbourhood where the volunteers live, as a development actor in health and education and as a provider of relief in times of emergencies. In addition, the MWF has transnational reach through its branches in the UK and elsewhere. Similarly, within the ALKF there are differences between the way the organization works at its headquarters, where it positions itself as a central actor in the mainstream aid and development field, and the way the organization works at the grassroots level through networks of party workers and ideological sympathizers.

In both organizations, the change in discourse is most evident in the ways the organizations communicate with external stakeholders and audiences through their websites and printed material, where they present themselves as modern and professional NGOs, aligned with key humanitarian principles. The ALKF and the MWF claim legitimacy by being professional aid organizations, drawing on professional authority. Yet, in both organizations, the old stakeholders (the members and sympathizers with the religious movements) are still important constituencies; they are the volunteers who enable the organization to respond quickly across Pakistan, and they remain the principal funders of the organizations' activities. To these stakeholders, religion-as doctrine, symbols and practice-remains an important source of authority, which the organizations draw on when they make claims to legitimacy among their traditional support base.

To manage organizational change, the MWF in the UK is applying a two-pronged strategy. To the internal audience, the leader is presented as a religious scholar, while to the external audience in the UK and Europe, they have made a conscious decision to portray the spiritual and political leader of MQI, Dr Tahir-ul-Qadri, as one of their managers put it as: 'a humanitarian and philanthropist. Not as an Islamic scholar'. This initiative came from the UK office and resembles that of other Muslim NGOs in the UK such as Islamic Relief, which have adopted the language of the development industry (Juul Petersen 2016). This resembles what has been described as a need to be bilingual, to master the languages of both development and of Islam (Khan 2012; Juul Petersen 2016). As seen in the case of the MWF, the organizations in this study employ different language, texts and symbols to claim legitimacy among diverse stakeholders in different contexts. The way the organizations present its leader to different audiences brings out the contextual nature of organizational legitimacy and reveals how the organizations are interpreting and appropriating the meaning of Islamic charity, aid and development in different contexts, drawing on symbols, language and authority both from Islamic traditions and from mainstream aid and development discourse.

\section{Conclusion: Experts of Islamic Aid}

In this article I have argued that the NGOization of Islamic charity involves processes of professionalization and depoliticization, and consequently, a change in the ways of practising, as well as conceiving of Islamic charity, aid and development. In order to claim legitimacy as providers of aid in changing institutional contexts, it appears that the organizations need to be both 'NGOs' and 'Islamic'. Combining ideals and practices of Islamic charity with principles and practices from mainstream aid and development, the organizations draw on both religious and professional sources of authority. In the process they reinterpret and give new meaning to Islamic charity, aid and development; in effect, they become Muslim NGOs. The analysis of the NGOization of Islamic charity has brought out the importance of normative frameworks in shaping organizational legitimacy.

For practising Muslims, giving charity is a religious duty and an integral part of religious practice. Helping the poor, the needy, widows and orphans, as emphasized in the religious texts, is 'the right thing to do'. Islamic aid organizations can be seen as knowing 'how to do it right', having the right procedures in place to manage alms in accordance with the religious prescriptions. As such, Muslim NGOs are 'right for the job', by being professionals in aid and development and by being Islamic.

Changing their field of engagement from charity-based handouts to humanitarian aid and development, Muslim NGOs become experts of Islamic aid: they are not only 'doing good', but they are doing it 'the modern Islamic way'. They present themselves as modern and professional, while they at the same time advance what they consider key Islamic values and ways of being Muslim, which resonate with the organizations' main supporters and sympathizers, members of the religious organizations and the broader Muslim public.

As this analysis has brought out, however, the organizations are becoming more complex and relate to a diverse set of stakeholders-both old and new-with different expectations. Through the process of NGOization, the organizations are making themselves legitimate among new stakeholders, reaching out beyond the party members to include broader, predominantly Muslim communities in Pakistan and its diaspora, but also in Turkey and the Gulf. Can these organizations be fully recognized by actors in the international field of aid and development if they continue with their institutionalized gender segregation, clearly breaking with the ideals of gender equality so central to mainstream development discourse and practice? And will they be able to reconcile the principle of non-discrimination with the interpretation of zakat rules common among 
South Asian Muslims? The changes in discourse and practices of aid present some potential dilemmas for these religio-political aid organizations. As their organizational identity changes, the organizations will need to balance the interests of old and new stakeholders and to negotiate their potentially conflicting norms and values. Whether they manage to keep their old constituencies, supporters and the network of volunteers that is so central to the operational reach of the organization-while at the same time be recognized as legitimate providers of aid among mainstream aid and development actors-is yet to be seen. It will likely require cautious positioning vis-à-vis Western NGOs and donors and a careful negotiation and management of the meaning given to Islamic charity, aid and development.

Islamic traditions of charity provide a normative framework which links social practice with transcendental authority. As argued above, this framework is not static, but changing with context and over time. By applying an understanding of organizational legitimacy as multifaceted and socially constructed, the importance of contextual and relational aspects of legitimacy has been emphasized, which hitherto has been given only scant attention in NGO research. Studying the transformation of Islamic charity further reveals the continued significance of religion-including its moral and transcendental aspects-in the discourses, practices and identities of Muslim NGOs.

Funding This study was funded by the Norwegian Research Council (Grant Number 207752).

\section{Compliance with Ethical Standards}

Conflict of interest The authors declare that they have no conflict of interest.

Open Access This article is distributed under the terms of the Creative Commons Attribution 4.0 International License (http://crea tivecommons.org/licenses/by/4.0/), which permits unrestricted use, distribution, and reproduction in any medium, provided you give appropriate credit to the original author(s) and the source, provide a link to the Creative Commons license, and indicate if changes were made.

\section{References}

Aga Khan Development Network (AKDN). (2000). Philanthropy in Pakistan: A report of the initiative on indigenous philanthropy. Islamabad: Aga Khan Development Network.

Agensky, J. C. (2013). Dr Livingstone, I presume? Evangelicals, Africa and faith-based humanitarianism. Global Society, 27(4), 454-474.

Alvarez, S. E. (2009). Beyond NGOization: reflections from Latin America. Development, 52(2), 175-184.
Banks, N., Hulme, D., \& Edwards, M. (2015). NGOs, states, and donors revisited: Still too close for comfort? World Development, 66, 707-718.

Bano, M. (2008). Dangerous correlations: Aid's impact on NGOs' performance and ability to mobilize members in Pakistan. World Development, 36(11), 2297-2313.

Bano, M. (2012). Welfare work and politics of Jama'at-i-Islami in Pakistan and Bangladesh. Economic and Political Weekly, 47(1), 86-93.

Barnett, M. (2005). Humanitarianism transformed. Perspectives on Politics, 3(04), 723-740.

Benthall, J. (1999). Financial worship: The Quranic injunction to alms giving. Journal of the Royal Anthropological Institute, 5(1), 27-42.

Benthall, J. (2012). 'Cultural proximity' and the conjuncture of Islam with modern humanitarianism. In M. Barnett \& J. G. Stein (Eds.), Sacred aid: Faith and humanitarianism. Oxford: Oxford University Press.

Berger, J. (2003). Religious nongovernmental organizations: An exploratory analysis. Voluntas: International Journal of Voluntary and Nonprofit Organizations, 14(1), 15-39.

Boli, J., \& Thomas, G. (1999). Constructing world culture. Stanford, CA: Stanford University Press.

Brinkerhoff, D. (2005). Organizational legitimacy, capacity and capacity development. Discussion paper no. 58A. Maastricht: European Centre for Development Policy Management.

Burke, K. C. (2012). Women's agency in gender-traditional religions: A review of four approaches. Sociology Compass, 6(2), 122-133.

Candland, C., \& Qazi, R. K. (2012). Civil conflict, natural disasters, and partisan welfare associations in the Islamic Republic of Pakistan. In S. A. Crabtree \& J. Parker (Eds.), The cup, the gun, and the crescent: Social welfare and civil unrest in Muslim societies. London: Whiting and Birch.

Chahim, D., \& Prakash, A. (2014). NGOization, foreign funding, and the Nicaraguan civil society. Voluntas: International Journal of Voluntary and Nonprofit Organizations, 25(2), 487-513.

Clark, J. A. (2004). Islam, charity and activism. Middle class networks and social welfare in Egypt, Jordan and Yemen. Bloomington, IN: Indiana University Press.

Clarke, G. (1998). Non-governmental organizations (NGOs) and politics in the developing world. Political Studies, 46(1), 36-52.

Clarke, G. (2008). Faith-based organizations and international development: An overview. In M. Jennings \& G. Clarke (Eds.), Development, civil society and faith-based organizations: Bridging the sacred and the secular. New York, NY: Palgrave Macmillan.

Clarke, M., \& Ware, V.-A. (2015). Understanding faith-based organizations: How FBOs are contrasted with NGOs in international development literature. Progress in Development Studies, 15(1), 37-48.

De Cordier, B. (2009). The 'humanitarian frontline', development and relief, and religion: What context, which threats and which opportunities? Third World Quarterly, 30(4), 663-684.

De Kadt, E. (2009). Should God play a role in development? Journal of International Development, 21(6), 781-786.

Ghaus-Pasha, A., \& Iqbal, M. A. (2003). Defining the nonprofit sector: Pakistan. Working papers of the Johns Hopkins comparative nonprofit sector project. Baltimore, MA: The Johns Hopkins Center for Civil Society Studies.

Göçmen, I. (2014). Religion, politics and social assistance in Turkey: The rise of religiously motivated associations. Journal of European Social Policy, 24(1), 92-103.

Grillo, R. D. (1997). Discourses of development. A view from anthropology. In R. D. Grillo \& R. L. Stirrat (Eds.), Discourses 
of development: Anthropological perspectives. New York, NY: Berg.

Grünenfelder, J. (2013). Negotiating gender relations: Muslim women and formal employment in Pakistan's rural development sector. Gender, Work and Organization, 20(6), 599-615.

Hilhorst, D. (2003). The real world of NGOs: Discourses, diversity and development. London: Zed.

Iqbal, M. A., \& Siddiqui, S. (2008). Mapping the terrain: The activities of faith-based organizations in development in Pakistan. Working paper No. 24, Religions and Development Research Programme. Birmingham: International Development Department, University of Birmingham.

Iqtidar, H. (2011). Secularizing Islamists?. Chicago, IL: University of Chicago Press.

IRIN. (2012). Analysis: Faith-based aid revolution in the Muslim world. http://www.irinnews.org/report/95564/analysis-a-faithbased-aid-revolution-in-the-muslim-world.

Juul Petersen, M. (2011). For the humanity or for the umma: Ideologies of aid in four transnational Muslim NGOs. Ph.D. thesis, University of Copenhagen, Copenhagen.

Juul Petersen, M. (2012a). Islamizing aid: Transnational Muslim NGOs after 9/11. Voluntas: International Journal of Voluntary and Nonprofit Organizations, 23(1), 126-155.

Juul Petersen, M. (2012b). Trajectories of transnational Muslim NGOs. Development in Practice, 22(5-6), 763-778.

Juul Petersen, M. (2016). For humanity or for the umma? Aid and Islam in international Muslim NGOs. London: C Hurst and $\mathrm{Co}$ Publishers Ltd.

Khan, A. A. (2012). Religious obligation or altruistic giving? Muslims and charitable donations. In M. Barnett \& J. G. Stein (Eds.), Sacred aid: Faith and humanitarianism (pp. 90-114). Oxford: Oxford University Press.

Kirmani, N. (2012). The role of religious values and beliefs in charitable and development organizations in Karachi and Sindh, Pakistan. Development in Practice, 22(5-6), 735-748.

Kirmani, N., \& Zaidi, S. (2010). The role of faith in the charity and development sector in Karachi and Sindh. Working paper No. 50, Religions and Development Research.

Lincoln, B. (2010). Holy terrors: Thinking about religion after September 11. Chicago, IL: University of Chicago Press.

Lister, S. (2003). NGO legitimacy technical issue or social construct? Critique of Anthropology, 23(2), 175-192.

Long, N. (2001). Development sociology: Actor perspectives. London: Routledge.

Meyer, J. W., \& Rowan, B. (1977). Institutionalized organizations: Formal structure as myth and ceremony. American Journal of Sociology, 83(2), 340-363.

Meyer, J. W., \& Scott, W. R. (1983). Centralization and the legitimacy problems of local government. In J. W. Meyer \& W. R. Scott (Eds.), Organizational environments: Ritual and rationality (pp. 199-215). Beverley Hills, CA: Sage.

Mitlin, D., Hickey, S., \& Bebbington, A. (2007). Reclaiming development? NGOs and the challenge of alternatives. World Development, 35(10), 1699-1720.
Nasr, S. V. R. (1994). The vanguard of the Islamic revolution: the Jama'at-i Islami of Pakistan. Berkeley, CA: University of California Press.

Novak, P. (2013). The success of NGOs. Development in Practice, 23(7), 872-888.

Ossewaarde, R., Nijhof, A., \& Heyse, L. (2008). Dynamics of NGO legitimacy: How organising betrays core missions of INGOs. Public Administration and Development, 28(1), 42-53.

Pakistan Centre for Philanthropy (PCP). (2010). Individual philanthropy in the Punjab. Islamabad: Pakistan Centre for Philanthropy.

Philippon, A. (2012). When Sufi tradition reinvents Islamic modernity: The Minhāj-ul Qur'ān, a neo-Sufi order in Pakistan. In C. Bennett \& C. M. Ramsey (Eds.), South Asian Sufis: Devotion, deviation, and destiny (pp. 21-44). London: Bloomsbury Publishing.

Philippon, A. (2014). A sublime, yet disputed, object of political ideology? Sufism in Pakistan at the crossroads. Commonwealth and Comparative Politics, 52(2), 271-292.

Sahi, A. (2015). Wings that restrain women. The News. Retrieved 15 January 2017 from http://tns.thenews.com.pk/political-partieswings-that-restrain-women/\#.WKrwYH_g_s5.

Salehin, M. M. (2016). Islamic NGOs in Bangladesh: Development, piety and neoliberal governmentality. London: Routledge.

Sezgin, Z., \& Dijkzeul, D. (2015). The new humanitarians in international practice: Emerging actors and contested principles. Abingdon: Routledge.

Strand, A., \& Borchgrevink, K. (2006). Review of Norwegian earthquake assistance to Pakistan 2005 and 2006. CMI paper. Bergen: Chr. Michelsen Institute.

Strothmann, L. (2013). Giving comfort, dispelling fear: Social welfare at the shrine of Data Ganj Bukhsh in Lahore, Pakistan. ERDKUNDE, 67(1), 49-61.

Suchman, M. C. (1995). Managing legitimacy: Strategic and institutional approaches. Academy of Management Review, 20(3), 571-610.

Thaut, L., Stein, J. G., \& Barnett, M. (2012). In defence of virtue: Credibility, legitimacy dilemmas, and the case of Islamic relief. In P. A. Gourevitch, D. A. Lake, \& J. G. Stein (Eds.), The credibility of transnational NGOs: When virtue is not enough (pp. 137-164). Cambridge: Cambridge University Press.

Tomalin, E. (2015a). The Routledge handbook of religions and global development. London: Routledge.

Tomalin, E. (2015b). Gender, development, and the 'de-privatisation' of religion: Reframing feminism and religion in Asia. In P. Fountain, R. Bush, \& R. M. Feener (Eds.), Religion and the politics of development: Critical perspectives on Asia (pp. 61-82). Basingstoke: Palgrave Macmillian.

Walton, O. E., Davies, T., Thrandardottir, E., \& Keating, V. C. (2016). Understanding contemporary challenges to INGO legitimacy: Integrating top-down and bottom-up perspectives. Voluntas: International Journal of Voluntary and Nonprofit Organizations, 27(6), 2764-2786.

Wilder, A. (2010). Aid and stability in Pakistan: Lessons from the 2005 earthquake response. Disasters, 34(3), 406-426. 